\title{
Effect of Organizational Justice on Organizational Commitment: Mediating Role of Intrinsic and Extrinsic Satisfaction
}

\author{
Dewiana Novitasari ${ }^{1}$, Masduki Asbari ${ }^{2}$, Muhamad Rizky Wijaya ${ }^{3}$, Teguh Yuwono ${ }^{4}$ \\ ${ }^{1,3,4}$ SekolahTinggiIlmuEkonomiInsan Pembangunan, Indonesia \\ ${ }^{2}$ STMIK Insan Pembangunan, Indonesia \\ ${ }^{2}$ Pelita Harapan University, Indonesia
}

\begin{abstract}
This study aimed to measure the effect of organizational justice on organizational commitment of the employee of a packaging manufacturer in Indonesia which are mediated by intrinsic and extrinsic job satisfaction. Data collection was done by simple random sampling to 271 population of employees. The returned and valid questionnaire results were 145 samples. Data processing was used SEM method with Smart PLS 3.0 software. The results of this study concluded that organizational justice have a positive and significant effect on intrinsic and extrinsic job satisfaction. Intrinsic and extrinsic job satisfaction have a positive and significant effect on organizational commitment. Organizational justice have not significant effect on organizational commitment. Intrinsic and extrinsic job satisfaction have a significant effect as mediator between organizational justice and organizational commitment. This new research proposed a model for building the organizational commitment among the employee of a packaging manufacturer in Indonesia through enhancing organizational justice with intrinsic and extrinsic job satisfaction as a mediator.
\end{abstract}

Keywords: Extrinsic job satisfaction, intrinsic job satisfaction, organizational commitment, organizational justice.

\section{INTRODUCTION}

Generally, every organization require a particular human resource (HR) that is proficient and capable to be the most significant element in order to achieve a desired target (Asbari, 2015, 2019). Human Resource Management (HRM) is necessary since the Human Resource (HR) has a major role to accomplish this target (Asbari, Fayzhall, et al., 2020; Pramono et al., 2020). A successful organization is able to be seen through obtaining a competent employee and maintaining their employees to work in the organization. By presenting an enjoyment and enthusiasm in working, also the desire to continue working and showing loyalty to the organization (Meyer et al., 1993) would give a positive image to the organizational commitment because it will be perceived as one of the methods to achieve a company's goal (Asbari et al., 2019; Imelda et al., 2020; Kusumaningsih et al., 2020; Yuwono et al., 2020). Managing and improving an organizational commitment could be achieved through prioritising justice (Bayasgalan \& Gerelkhuu, 2016; Musringudin et al., 2017).

Ways of maintaining an outstanding employee's commitment could be through an organizational justice for the employee and support from fellow members, especially from the employer. Organizational justice is showed through perception of the employees, which is able to give a positive influence to the organization. Organizational justice is supported by an evaluation based on the organizational justice dimensions, which consist of distributive, procedural and interactional justice and these dimensions are related to interpersonal and informational (Niehoff \& Moorman, 1993). According to some research, it was reported that organizational justice provides a positive influence towards organizational commitment (Cheah et al., 2016; Li et al., 2016). However, some other research concluded that the influence given from organizational justice towards organizational commitment was not proven (Lambert et al., 2007). The difference from the research results shows a gap which creates inconsistency in the relationship between organizational justice variable and organizational commitment. Therefore, researchers offered a variable in the shape of job satisfaction, which consist of intrinsic and extrinsic satisfaction as the mediation variables. On the other hand, job satisfaction has a significant role in order for the employees to have a high commitment during their work in the organization. 
When an organizational commitment is presented with the employee's enjoyment in working, that feeling is caused by the job satisfaction felt by the employees so it portrays an organizational behaviour, which is the organizational commitment itself. Job satisfaction is any positive atmosphere felt by a particular person as a result of their own characteristic evaluation (Stephen P. Robbins \& Judge, 2008). Analysing on how significant an organization to make an effort on improving organizational commitment, also based on an discovery of research gap from some analysis, then this study has a detailed exploration in terms of the relationship and influence of organizational justice. Additionally, a job satisfaction towards an organizational commitment for employees in one of the amanufacturerin Indonesia, Indonesia.

\section{LITERATURE REVIEW AND HYPOTHESIS DEVELOPMENT}

\section{A. Organizational Justice}

Organizational justice is defined as an employee's perception on justice that is occurred in a particular organization. A justice is shown when there is a presence of dedication and action from the management point of view towards the employee through great morality by way of ethics, religion or law standards (Greenberg, 1990). Perception regarding a certain sense of justice towards employee is relevant and may be behaviourally influential for them, which might cause the willingness of resignation, employee's job satisfaction, as well as commitment and their involvement in working (Agistiawati et al., 2020; Hutagalung et al., 2020; Sudiyono, Fikri, et al., 2020; Sudiyono, Goestjahjanti, et al., 2020). Justice in an organization would greatly affect the employee's attitudes in order to receive justice in a welcome manner, which would give impacts towards the organizational performance and reduce any form of conflicts between employers and their employees. Referring to the study of theories and dimensions from (Moorman, 1991), organizational justice indicators consist of distributive justice indicator, procedural justice indicator, and interactional justice indicator.

\section{B. Job Satisfaction}

Job satisfaction is referred as an attitude that is shown by the employees, which could be negative or positive towards their own duties (Greenberg, 2011). Job satisfaction could also be defined as any form of positive feeling that is felt by a certain person as the result of their own characteristic evaluation (S. P. Robbins \& Judge, 2001). Furthermore, (Weiss et al., 1967) has shown three dimensions of job satisfaction that is referred to Minnesota Satisfaction Questionnaire (MSQ), which are intrinsic satisfaction, extrinsic satisfaction, and also general satisfaction. This study has used two dimensions which covers eighteen indicators. Firstly, intrinsic satisfaction - denoted as satisfaction that is related to a certain person's success in order to carry out their work well, where this satisfaction emerge from the presence of intrinsic factor. Moreover, extrinsic satisfaction, which stands for satisfaction as an impact of extrinsic factor influence (external factor) such as a reward that is obtained from individuals, where this reward could be in a form of salary or appreciation as well as a recognition of success. This study much explains the same way as Herzberg (2003) clustered two different factors in job satisfaction, which are intrinsic factor and extrinsic factor.

\section{Organizational Commitment}

Holding a commitment in a particular organization is a form of emerging employee's behavior towards the job that they carry out. Commitment is one of identification systems towards employee's condition assisting a certain organization as well as their aims and goal in maintaining the organization's membership (Stephen P. Robbins \& Judge, 2008). Organizational commitment implicated the acceptance of direction and the organization's purpose including the strong eagerness to be a part of organization (Kreitner \& Kinicki, 2014). This matter means the availability of a strong determination from a particular employee to withstand their role in the organization in order to participate in achieving the organization's goal. Organizational commitment also denoted as a strong desire to be a permanent member of the organization; the ambition to work hard correspond to the organization's vision and mission; acknowledgement of value and purpose of the organization. In other words, organizational commitment is any attitude that reflects employee's loyalty to the organisation to reach success and continuous progress (Luthans, 2005). Along with the development of theory of organizational commitment, referring to (Allen \& Meyer, 1990) who expressed the definition regarding commitment in being organized in a particular psychological construction, which means the characteristic of the relationship between members of organization and the organization itself also having implications towards individual's decision to continue their membership in the organization. Organizational commitment provides member's ideas from a 
particular organisation in order to give loyalty and contribution towards organization. To conclude the theory explained above, organizational commitment tend to state the employee's feeling that it gives an image as a form of desire, need and responsibility for the employee towards the organization.

\section{Relationship between Organizational Justice and Job Satisfaction}

Organizational justice gives a great impact towards job satisfaction specifically to the employees (Cheah et al., 2016; Jiang et al., 2015; Li et al., 2016; Minibas-Poussard et al., 2017; Rahman et al., 2016). Organizational justice has a significant part in the process in organization that would bring influence to the employees in order to achieve job satisfaction (Afridi \& Baloch, 2018; Ajala, 2017; Bayarçelik \& Findikli, 2016; Kashif et al., 2016). Normally, employee that is able to sense a justice when distributive justice is received correspond to what the employee has given to the company for the effort of finishing their tasks. Other than that, it is important to keep procedural justice in mind in order to accomplish the deal between two perspectives related to the regulation that has been determined. Certainly, a role from a manager is needed in achieving job satisfaction of employees in order to maintain interactional justice that is connected to the respectful and appreciative attitudes, as well as being open in terms of communication. In overall, organizational justice provides practical benefits to job satisfaction. There are scarcely few numbers of researchers that has explored the connection between organizational justice and job satisfaction dimensions in the matter of intrinsic satisfaction and extrinsic satisfaction (Calvo-salguero et al., 2011; Randolph, 2005). According to some previous discovery also its study based on the theories that have been determined, thus researchers have stated the hypothesis:

H1: Organizational justice has a positive and significant impact towards intrinsic job satisfaction of the employees of a packaging manufacturer in Indonesia.

H2: Organizational justice has a positive $n$ significant impact towards extrinsic job satisfaction of the employees of a packaging manufacturer in Indonesia.

\section{E. Relationship between Organizational Justice and Organizational Commitment}

Organization that is able to provide organizational justice either from the aspect of distributive, procedural or interactional justice, then certainly organizational commitment towards employees would improve (Jang et al., 2019; Jiang et al., 2015). Organizational commitment is mostly affected by the distributive and procedural justice, (Rahman et al., 2016) stated that organizational commitment occurred to teachers or employees is caused by organizational justice, where this could be proven by equal giving towards the employees. Interactional justice would give influence to commitments ( $\mathrm{Li}$ et al., 2016). In conclusion, organizational justice is one of the things that would influence organizational commitment to employees (Cheah et al., 2016). in organizational justice theory, interactional justice dimension would tend to give impacts to the organizational commitment. This is caused by any form of interactions from interpersonal justice between employees and their manager. Any structure of interpersonal justice that would create organizational commitment is usually accompanied with treatment from the manager to glorify, respect and be polite in interacting with their employees (Kreitner \& Kinicki, 2014). According to previous discovery and its study based on theory that has been determined, thus researchers have stated their hypothesis:

H3: Organizational justice has a positive and significant impacts towards organizational commitment of the employees of a packaging manufacturer in Indonesia.

\section{F. Relationship between Job Satisfaction and Organizational Commitment}

Previous researchers have found evidence that job satisfaction would give a significant influence towards organizational commitment (Bayarçelik \& Findikli, 2016; Lambert et al., 2019). Including other previous researchers also have found the same matter (Beshlideh et al., 2018; Ćulibrk et al., 2018; Hazriyanto \& Ibrahim, 2019; Musringudin et al., 2017; Soomro \& Shah, 2019). As explained by (Weiss et al., 1967) regarding job satisfaction could be based on a favourable outcome from carrying out their task, it could also be in a form of extrinsic satisfaction appearing as a reward that is correspond to the job they carry out, even satisfaction that is obtained through a supportive work environment for the employee in order to do their job. There are only few numbers of researchers that have discovered the connection of all of the job satisfaction dimensions, in this 
matter is the relationship between intrinsic and extrinsic satisfaction with organizational commitment. From those researchers, there is at least one of them have found an evidence that intrinsic and extrinsic satisfaction has significant impact towards organizational commitment (Ismail \& Razak, 2016). According to previous discoveries as well as its study about theory that has been determined, thus researchers have stated their hypothesis:

H4: Intrinsic job satisfaction has positive and significant impact on organizational commitment of the employees of a packaging manufacturer in Indonesia.

H5: Extrinsic job satisfaction has positive and significant impact on organizational commitment of the employees of a packaging manufacturer in Indonesia.

\section{G. Relationship between Organizational Justice and Organizational Commitment through Job Satisfaction as Mediation}

A particular organization makes serious effort to create assets of human resource (HR) that has strong commitment towards the organization. One of the ways is by improving job satisfaction of the employees (Asbari, Bernarto, et al., 2020; Bernarto et al., 2020; Imelda et al., 2020; Sudiyono, Fikri, et al., 2020). Some researchers have concluded that job satisfaction have become a mediator variable in the relationship between organizational justice and organizational commitment, among these are researches from (Chegini et al., 2019; Saadati et al., 2016). According to previous discoveries as well as its study about theory that has been determined, thus researchers have stated their hypothesis:

H6: Organizational justice has positive and significant impact on organizational commitment through intrinsic job satisfaction as mediation.

H7: Organizational justice has positive and significant impact on organizational commitment through extrinsic job satisfaction as mediation.

\section{H. Research Model}

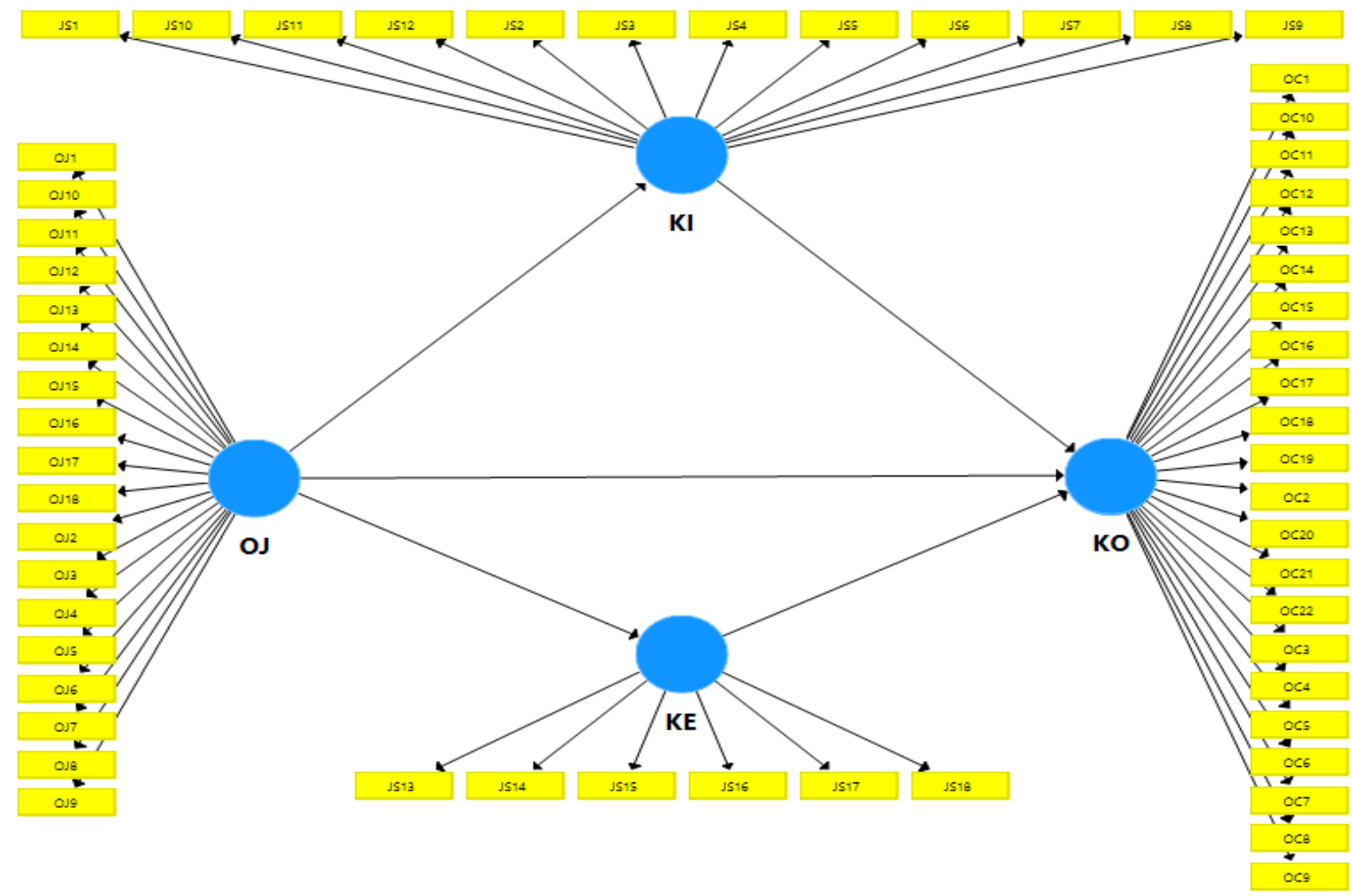


According to (Sekaran \& Bougie, 2003), every research project should be based on the scientific and rational theoretical structure because it may help to arrange a hypothesis, which could be examined to find out whether the formulated theory is valid or not. Furthermore, this theory could be measured with appropriate analysis and statistics. Referring to the theory and previous research, there is a relationship between the variables, which are organizational justice, job satisfaction and organizational commitment. Organizational justice is referred by the research parameter (Moorman, 1991), while job satisfaction is introduced by the research parameter (Weiss et al., 1967), and organizational commitment is pointed out by research parameter (Meyer \& Allen, 1991). The author created this research model as shown in Figure

\section{METHOD}

\section{A. Definition of Operational Indicator and Variable}

Method that is used in this research is quantitative method. Data collection has been done through distribution questionnaire to 271 population of the employee of a packaging industry in Indonesia and valid sample were 145. Instruments of this research 18 items (OJ1-OJ18) for organizational justice that adapted from (Moorman, 1991). Job satisfaction adapted form (Weiss et al., 1967) which used 12 items (JS1-JS12) for intrinsic job satisfaction and 6 items (JS13-JS18) for extrinsic job satisfaction. Meanwhile, organizational commitment is adapted from (Meyer \& Allen, 1991) with used 22 items (OC1-OC22). All variables in the list of items could be seen in the Appendix. Questionnaire is closely designed except for the questions/statements regarding respondent identity in a form of semi-opened questionnaire. Every item in a closed questions/statements is given five answer options, which consist of: strongly agree (5 points), agree (4 points), neutral ( 3 points), disagree ( 2 points), and strongly disagree (1 point). Methods for data preparations is done by PLS and the used of SmartPLS version 3.0 software as the tool.

\section{B. Population and Sample}

The population used in this research is the employee in one of a manufacturer in Indonesia with a number of 271 people. Questionnaire is distributed through a simple random sampling technique. The questionnaire result that is returned and is valid has a number 145 samples (percentage of 53.51 of the population).

\section{RESULTS AND DISCUSSION}

\section{A. Sample Description}

TABEL I

DESCRIPTIVE SAMPLE INFORMATION

\begin{tabular}{llcc}
\hline & Criteria & Amount & \% \\
\hline Age (per Oktober 2019) & $<30$ years old & 30 & $20.7 \%$ \\
& $30-40$ years & 63 & $43.4 \%$ \\
& old & 52 & $35.9 \%$ \\
& $>40$ years old & & $11.7 \%$ \\
& $<5$ years old & 17 & $58.6 \%$ \\
& $5-10$ years old & 85 & $29.7 \%$ \\
\hline Working period as an employee & $>10$ years old & 43 & $11.7 \%$ \\
& Bachelor & 17 & $75.2 \%$ \\
& degree & 109 & $13.1 \%$ \\
& Senior High & & \\
\hline Last formal education & S Junior High & 19 & \\
& School & & \\
& &
\end{tabular}

\section{B. Validity Test Result and Research Indicator Reliability}


Stages on testing model of measuring involve convergent validity test and discriminant validity. While value of cronbach's alpha and composite reliability are needed in testing for construction reliability. PLS analysis result could be used to test for research hypothesis if all indicators in PLS model has meet the requirements of convergent validity, discriminant validity and reliability test.

\section{Convergent Validity Testing}

Convergent validity test is done by seeing the value of loading factor of each indicators towards the construct. In most reference, with factor weighing from at least 0.5 is considered having validity that is strong enough to explain the latent construct (Chin, 1998; Ghozali, 2014; Hair et al., 2010). In this research, minimum limit of loading factor that is accepted is 0.5, with the condition of AVE score for every construct, which is $>0.5$ (Ghozali, 2014). After passing the process of Smart PLS 3.0, there are some indicators or items that needs to be taken out from the model. Furthermore, all indicators should have loading factor score above 0.5 or has meet the condition of AVE score above 0.5. Model that is fit and valid from the research could be seen on Figure 2. Therefore, convergent validity from this research model has meet all of the requirements. Loading score, cronbach's alpha, composite reliability and AVE in every construct can be seen in Table 2 below:

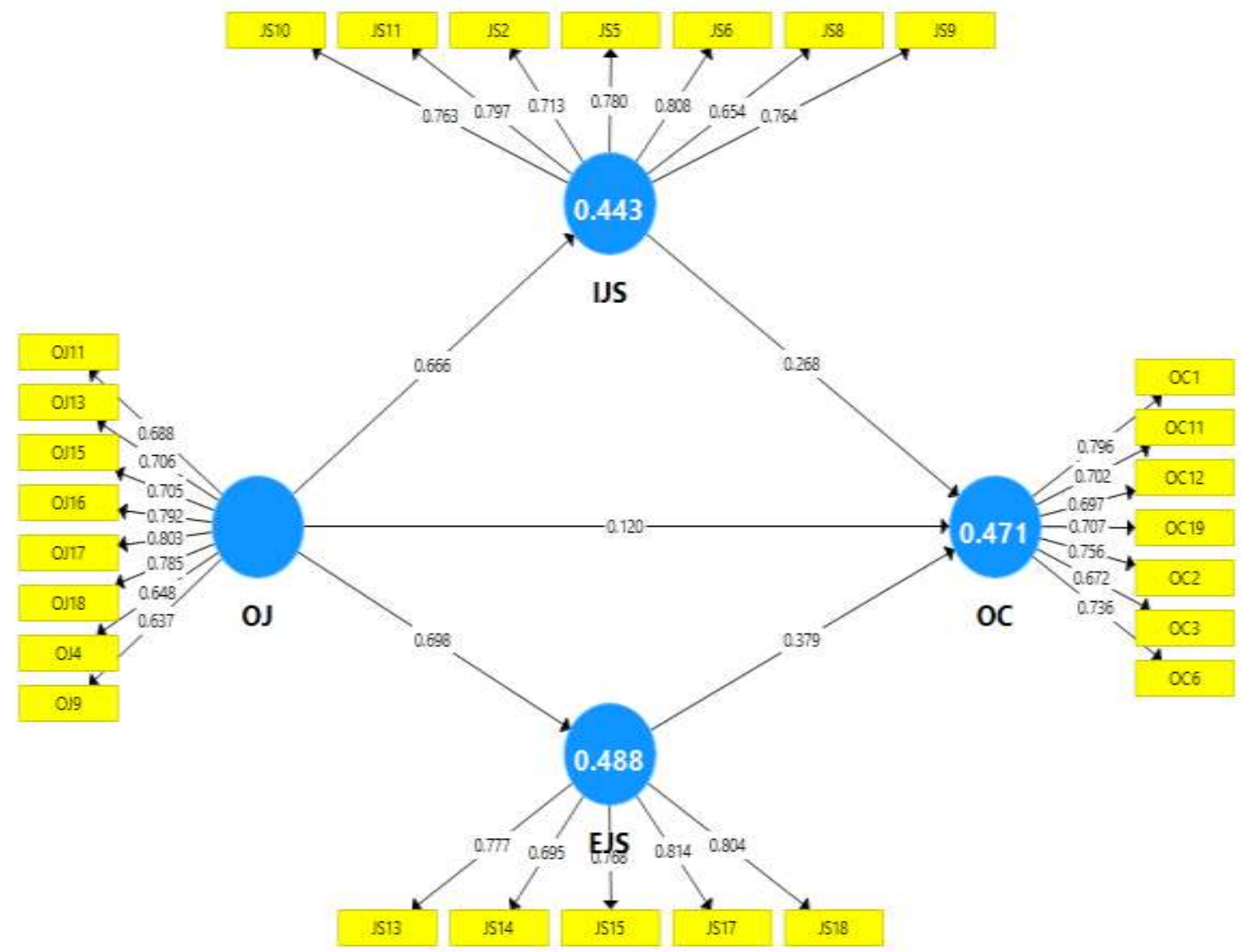

Figure 2. Model Fit

\section{TABLE II}


ITEMS LOADINGS, CRONBACH'S ALPHA, COMPOSITE RELIABILITY, AND AVERAGE
VARIANCE EXTRACTED (AVE)

\begin{tabular}{|c|c|c|c|c|c|}
\hline Variables & Items & Loadings & $\begin{array}{l}\text { Cronbach's } \\
\text { Alpha }\end{array}$ & $\begin{array}{l}\text { Composite } \\
\text { Reliability }\end{array}$ & AVE \\
\hline \multirow{8}{*}{$\begin{array}{l}\text { Organizational justice } \\
\text { (OJ) }\end{array}$} & OJ11 & 0.716 & 0.868 & 0.897 & 0.523 \\
\hline & OJ13 & 0.680 & & & \\
\hline & OJ15 & 0.733 & & & \\
\hline & OJ16 & 0.806 & & & \\
\hline & OJ17 & 0.813 & & & \\
\hline & OJ18 & 0.808 & & & \\
\hline & OJ4 & 0.589 & & & \\
\hline & OJ9 & 0.648 & & & \\
\hline \multirow{7}{*}{$\begin{array}{l}\text { Intrinsic Job Satisfaction } \\
\text { (IJS) }\end{array}$} & JS10 & 0.773 & 0.875 & 0.905 & 0.571 \\
\hline & JS11 & 0.807 & & & \\
\hline & JS2 & 0.721 & & & \\
\hline & JS5 & 0.740 & & & \\
\hline & JS6 & 0.738 & & & \\
\hline & JS8 & 0.714 & & & \\
\hline & JS9 & 0.755 & & & \\
\hline \multirow{6}{*}{$\begin{array}{l}\text { Extrinsic Job Satisfaction } \\
\text { (EJS) }\end{array}$} & JS13 & 0.790 & 0.832 & 0.881 & 0.597 \\
\hline & JS14 & 0.715 & & & \\
\hline & JS15 & 0.764 & & & \\
\hline & JS16 & 0.427 & & & \\
\hline & JS17 & 0.776 & & & \\
\hline & JS18 & 0.812 & & & \\
\hline \multirow{8}{*}{$\begin{array}{l}\text { Organizational Commitment } \\
\text { (OC) }\end{array}$} & $\mathrm{OC} 1$ & 0.785 & 0.849 & 0.885 & 0.526 \\
\hline & OC11 & 0.688 & & & \\
\hline & OC12 & 0.703 & & & \\
\hline & OC19 & 0.716 & & & \\
\hline & OC2 & 0.784 & & & \\
\hline & OC20 & 0.623 & & & \\
\hline & OC3 & 0.693 & & & \\
\hline & OC6 & 0.731 & & & \\
\hline
\end{tabular}

TABEL III

\section{DISCRIMINANT VALIDITY}

\begin{tabular}{lllll}
\hline \multicolumn{1}{c}{ Variables } & EJS & IJS & OC & OJ \\
\hline Extrinsic Job Satisfaction (EJS) & $\mathbf{0 . 7 7 3}$ & & & \\
Intrinsic Job Satisfaction (IJS) & 0.664 & $\mathbf{0 . 7 5 6}$ & & \\
Organizational Commitment (OC) & 0.641 & 0.600 & $\mathbf{0 . 7 2 5}$ & \\
Organizational justice (OJ) & 0.698 & 0.666 & 0.563 & $\mathbf{0 . 7 2 3}$ \\
\hline
\end{tabular}

TABEL IV

COLLINEARITY STATISTICS (VIF)

\begin{tabular}{lccc}
\hline \multicolumn{1}{c}{ Variables } & EJS & IJS & OC \\
\hline Extrinsic Job Satisfaction (EJS) & & & 2.266 \\
Intrinsic Job Satisfaction (IJS) & & & 2.085 \\
Organizational Commitment (OC) & & & 2.276 \\
Organizational justice $(O J)$ & 1.000 & 1.000 & \\
\hline
\end{tabular}

\section{Discriminant Validity Test}


Discriminant validity is done to ensure that every concept of each latent variables are in contrast with the other latent variables. A model has a good discriminant validity if the quadratic value of AVE in each exogeneous construct (value on the diagonal) exceeds the correlation between the construct with the other construct (value below diagonal) (Ghozali, 2014). Result of discriminant validity research is done by the quadratic value of AVE, which means by seeing the Fornell-Larcker Criterion Value that is obtained the same way as shown in Table 3.

Discriminant validity test result shown in Table 3 indicates the whole construct having square root value of AVE above correlation value with the other latent construct (through Fornell-Larcker Criterion) including crossloading value of the whole item from any indicator that is larger than the other indicator items as mentioned in Table 4, so it can be concluded that a model has meet a discriminant validity (Fornell\&Larcker, 1981).

Moreover, collinearity evaluation is done to discover whether there is a collinearity in the model. To find out about collinearity, VIF estimation from every construct is required. If the VIF score is higher than 5, then the model will show a collinearity(Hair et al., 2014). It is shown the same way as in Table 4, all VIF score that is less than 5 means that the model has no collinearity.

\section{Construct Reliability Test}

Construct reliability can be assessed from the value of cronbach's alpha and composite reliability from each construct. Value of composite reliability and cronbach's alpha is suggested to be more than 0.7 (Ghozali, 2014). Reliability test result in the Table 2 above shows that all construct has composite reliability value and Cronbach's alpha value higher than 0.7 (> 0.7). In conclusion, all construct has meet the reliability that is required.

\section{Hypothesis Examination}

Hypothesis test in PLS is also denoted as inner model test. This test covers significance test that has a direct and indirect impact as well as how large is the measurement of the exogenous variable impact towards the endogenous variable. To discover the impact of organizational justice towards organizational commitment is through intrinsic and extrinsic job satisfaction as a mediation variable that needs a direct and indirect impact test. Impact test is done by using T-Statistic test in an analysis model called Partial Least Squared (PLS) with the help of SmartPLS 3.0 software. With the bootstrapping technique, R square value and significance test value can be obtained as shown in Table 5 and Table 6 below:

TABLE V

R SQUARE VALUE

\begin{tabular}{lcc}
\hline & R Square & R Square Adjusted \\
\hline Extrinsic Job Satisfaction (EJS) & 0.488 & 0.484 \\
Intrinsic Job Satisfaction (IJS) & 0.443 & 0.439 \\
Organizational Commitment (OC) & 0.471 & 0.460 \\
\hline
\end{tabular}

TABEL VI

HYPOTHESES TESTING

\begin{tabular}{llclccl}
\hline Hypotheses & Relationship & Beta & SE & T Statistics & P-Values & Decision \\
\hline H1 & OJ -> IJS & 0.666 & 0.044 & 15.011 & 0.000 & Supported \\
H2 & OJ -> EJS & 0.698 & 0.063 & 11.036 & 0.000 & Supported \\
H3 & OJ -> OC & 0.120 & 0.103 & 1.165 & 0.245 & Not Supported \\
H4 & IJS -> OC & 0.268 & 0.084 & 3.208 & 0.001 & Supported \\
H5 & EJS -> OC & 0.379 & 0.110 & 3.449 & 0.001 & Supported \\
H6 & OJ -> IJS -> OC & 0.179 & 0.057 & 3.112 & 0.002 & Supported \\
H7 & OJ -> EJS -> OC & 0.265 & $0.076-$ & 3.493 & 0.001 & Supported \\
\hline
\end{tabular}


As shown in Table 5 above, the $\mathrm{R}$ square value of intrinsic job satisfaction (IJS) is 0.443 which means the intrinsic job satisfaction variable (IJS) is able to be explained by organizational justice variable (OJ) in the value percentage of $44.3 \%$. Meanwhile, the other $55.7 \%$ percentage value can be explained by the other variables that are not discussed in this research. R square value of extrinsic job satisfaction (EJS) is 0.488 , which means the extrinsic job satisfaction variable can be explained by organizational justice $(\mathrm{OJ})$ variables, in the percentage of $48.8 \%$, while the other $51.2 \%$ can be interpreted by the other variables not discussed in this research. R square value of organizational commitment (OC) is 0.471 , which means organizational commitment variable can be interpreted by organizational justice variable, intrinsic and extrinsic job satisfaction (IJS \& EJS) with the percentage of $47.1 \%$, while the other $52.9 \%$ can be explained by other variables that is not discussed in this research. Meanwhile, Table 5 shows T-Statistics and P-Values that indicates impact between research variable that mentioned above.

\section{Discussion}

\section{Impact of Organizational Justice on Intrinsic Job Satisfaction}

According to the test results and its summary shown in Table 6, this research concludes that organizational justice gives a positive and significant influence towards intrinsic job satisfaction. This can be proven by the TStatistics value (OJ -> IJS) that has a value of 15.011, which is larger than 1.96, this is also confirmed by the value of P-Values of 0.000 , which is smaller than 0.05. This means that the hypothesis H1 is accepted (confirmed). This test result supports every previous research conclusion (Afridi \& Baloch, 2018; Ajala, 2017; Bayarçelik \& Findikli, 2016; Kashif et al., 2016). In addition to research of (Putra \& Indrawati, 2018) who stated that the better organizational justice carried out in a particular company, the more the company would create job satisfaction for the employees in Rama PhalaUbud Hotel.

\section{Impact of Organizational Justice on Extrinsic Job Satisfaction}

According to the test result and its summary shown in Table 6, this research concludes that organizational justice gives positive and significant impact towards extrinsic job satisfaction. This is proven by the T-Statistics value (OJ -> EJS) that has a value of 11.036, which is larger than 1.96, this is also confirmed by the value of PValues of 0.000, which is smaller than 0.05. this means that the hypothesis $\mathrm{H} 2$ is accepted (confirmed). This test results supports every previous research conclusion of (Afridi \& Baloch, 2018; Ajala, 2017; Bayarçelik \& Findikli, 2016; Kashif et al., 2016) as well as (Putra \& Indrawati, 2018), who stated that the better organizational justice carried out in a particular company, the more the company would create job satisfaction for the employees.

\section{Impact of Organizational Justice on Organizational Commitment}

According to the test result and its summary shown in Table 6, this research concludes that organizational justice have not significant impact on organizational commitment. This is proven by the T-Statistics value (OJ -> OC) that has a value of 1.165 , which is smaller than 1.96 , this is also confirmed by the value of P-Values of 0.245 , which is larger than 0.05. this means that the hypothesis H3 was rejected (not supported). This test results supports every previous research conclusion of (Lambert et al., 2007) who proven that there is no impact given from organizational justice towards organizational commitment.

\section{Impact of Intrinsic Job Satisfaction on Organizational Commitment}

According to the test result and its summary shown in Table 6, this research concludes that intrinsic job satisfaction gives positive and significant impact towards organizational commitment. This is proven by the $\mathrm{T}$ Statistics value (IJS -> OC) that has a value of 3.208, which is larger than 1.96, this is also confirmed by the value of P-Values of 0.001 , which is smaller than 0.05 . this means that the hypothesis $\mathrm{H} 4$ is accepted (confirmed). This test results supports every previous research conclusion of (Ismail \& Razak, 2016) as well as the other researchers, in job satisfaction construct that could not be separated from its dimension, (Beshlideh et al., 2018; Ćulibrk et al., 2018; Hazriyanto \& Ibrahim, 2019; Musringudin et al., 2017; Soomro \& Shah, 2019) has proven the same result for this. 


\section{Impact of Extrinsic Job Satisfaction on Organizational Commitment}

According to the test result and its summary shown in Table 6, this research concludes that extrinsic job satisfaction gives positive and significant impact towards organizational commitment. This is proven by the TStatistics value (EJS -> OC) that has a value of 3.449, which is larger than 1.96, this is also confirmed by the value of P-Values of 0.001, which is smaller than 0.05. this means that the hypothesis H5 is accepted (confirmed). This test results supports every previous research conclusion of (Ismail \& Razak, 2016) as well as the other researchers, in job satisfaction construct that could not be separated from its dimension, (Beshlideh et al., 2018; Ćulibrk et al., 2018; Hazriyanto \& Ibrahim, 2019; Musringudin et al., 2017; Soomro \& Shah, 2019) has proven the same result for this.

\section{Impact of Organizational Justice on Organizational Commitment through Intrinsic Job Satisfaction as Mediation}

According to the test result and its summary shown in Table 6, this research concludes that organizational justice gives positive and significant impact towards organizational commitment that is mediated by intrinsic job satisfaction. This is proven by the T-Statistics value (OJ -> IJS -> OC) that has a value of 3.112, which is larger than 1.96, this is also confirmed by the value of P-Values of 0.002 , which is smaller than 0.05 . this means that the hypothesis H6 is accepted (confirmed). This results prove that when there is an improvement in job satisfaction based on organizational justice, thus will show organizational commitment between employees. This test results supports every previous research conclusion of (Saadati et al., 2016), (Kim \& Chung, 2018; Suifan et al., 2017) and (Lambert et al., 2019) who confirmed that job satisfaction would give impact on the relationship between organizational justice and organizational commitment.

\section{Impact of Organizational Justice on Organizational Commitment through Extrinsic Job Satisfaction as Mediation}

According to the test result and its summary shown in Table 6, this research concludes that organizational justice gives positive and significant impact towards organizational commitment that is mediated by extrinsic job satisfaction. This is proven by the T-Statistics value (OJ -> EJS -> OC) that has a value of 3.493, which is larger than 1.96, this is also confirmed by the value of P-Values of 0.001 , which is smaller than 0.05 . this means that the hypothesis $\mathrm{H} 7$ is accepted (confirmed). Therefore, it can be concluded that the conjecture to this research regarding the impact on the role of mediation in extrinsic job satisfaction to the relationship between organizational justice and organizational commitment giving positive and significant impact is confirmed. This test results is supported by every previous research conclusion of (Darmawan \& Putri, 2017) and (Mohamad, 2012).

\section{CONCLUSIONS}

According to the data analysis result through questionnaire that is distributed to respondent, thus few conclusions have been made: firstly, organizational justice gives positive and significant impact on intrinsic and extrinsic job satisfaction. Secondly, organizational justice have not significant impact on organizational commitment. Thirdly, intrinsic an extrinsic job satisfaction gives positive impact towards organizational commitment. Lastly, intrinsic and extrinsic job satisfaction mediated the relationship between organizational justice and organizational commitment.

\section{REFERENCES}

[1] Afridi, A. A., \& Baloch, Q. B. (2018). The Effect of Organizational Justice on Job Satisfaction: A Comparative Study of Public and Private Universities of Khyber Pakhtunkhwa. Abasyn Journal of Social Sciences, 11(1), 237-253.

[2] Agistiawati, E., Asbari, M., Basuki, S., Yuwono, T., \& Chidir, G. (2020). Exploring the Impact of Knowledge Sharing and Organizational Culture on Teacher Innovation Capability. International Journal of Science and Management Studies (IJSMS), 3(3), 62-77. http://www.ijsmsjournal.org/current-issue.html

[3] Ajala, E. M. (2017). A RELATIONSHIP STUDY BETWEEN ORGANISATIONAL JUSTICE AND JOB SATISFACTION AMONG INDUSTRIAL EMPLOYEES IN OGUN STATE, NIGERIA. AFRICAN JOURNAL FOR THE PSYCHOLOGICAL STUDY OF SOCIAL ISSUES, 20(2), 26-42. http://www.ajpssi.org/index.php/ajpssi/article/view/223 
[4] Allen, N. J., \& Meyer, J. P. (1990). The measurement and antecedents of affective, continuance and normative commitment to the organization. Journal of Occupational Psychology, 63, 1-18. https://doi.org/https://doi.org/10.1111/j.2044-8325.1990.tb00506.x

[5] Asbari, M. (2015). Fokus Satu Hebat. Penerbit Dapur Buku.

[6] Asbari, M. (2019). Pengaruh kepemimpinan transformasional dan iklim organisasi terhadap kinerja dosen. JOCE IP, 13(2), 172186. http://jurnal.ipem.ac.id/index.php/joce-ip/article/view/187

[7] Asbari, M., Bernarto, I., Pramono, R., Purwanto, A., Hidayat, D., Sopa, A., Alamsyah, V. U., Senjaya, P., Fayzhall, M., \& Mustofa. (2020). The effect of work-family conflict on job satisfaction and performance: A study of Indonesian female employees. International Journal of Advanced Science and Technology, 29(3), 6724-6748. http://sersc.org/journals/index.php/IJAST/article/view/7325

[8] Asbari, M., Fayzhall, M., Goestjahjanti, F. S., Winanti, Yuwono, T., Hutagalung, D., Basuki, S., Maesaroh, S., Mustofa, Chidir, G., Yani, A., \& Purwanto, A. (2020). Peran Kepemimpinan Transformasional Dan Organisasi Pembelajaran Terhadap Kapasitas Inovasi Sekolah. EduPsyCouns: Journal of Education, Psychology and Counseling, 2(1), 6724-6748. https://ummaspul.ejournal.id/Edupsycouns/article/view/421

[9] Asbari, M., Purwanto, A., \& Santoso, P. B. (2019). Influence of Leadership, Motivation, Competence, Commitment and Culture on ISO 9001:2015 Performance in Packaging Industry. Scholars Journal of Economics, Business and Management, 8875, 577-582. https://doi.org/10.36347/sjebm.2019.v06i12.005

[10] Bayarçelik, E. B., \& Findikli, M. A. (2016). The Mediating Effect of Job Satisfaction On The Relation Between Organizational Justice Perception And Intention To Leave. Procedia - Social and Behavioral Sciences, 235(October), 403-411. https://doi.org/10.1016/j.sbspro.2016.11.050

[11] Bayasgalan, T., \& Gerelkhuu, T. (2016). THE IMPACTS OF ORGANIZATIONAL JUSTICE AND CULTURE, KNOWLEDGE MANAGEMENT AND EMPLOYEE ENGAGEMENT ON EMPLOYEE'S JOB SATISFACTION: THE CASE OF SUPPORTIVE SERVICE OFFICERS. Mongolian Journal of Agricultural Sciences, 19(3), 56-65. https://mongoliajol.info/index.php/MJAS/article/view/736

[12] Bernarto, I., Bachtiar, D., Sudibjo, N., Suryawan, I. N., Purwanto, A., \& Asbari, M. (2020). Effect of transformational leadership, perceived organizational support, job satisfaction toward life satisfaction: Evidences from indonesian teachers. International Journal of Advanced Science and Technology, 29(3), 5495-5503. http://sersc.org/journals/index.php/IJAST/article/view/6057

[13] Beshlideh, K., Sharifi, R., Hashemi, S. E., \& Naami, A. (2018). Testing a model of perceived organizational support, citizenship behavior, commitment, job satisfaction and leader-member exchange as concequences of servant leadership in cement factory employees in Kermanshah. International Journal of Psychology (IPA), 12(2), 169-196. https://doi.org/10.24200/ijpb.2018.115440.

[14] Calvo-salguero, A., Salinas, J., Martínez-de-Lecea, \& Carrasco-González, A.-M. (2011). Work - Family and Family - Work Conflict $\square$ : Does Intrinsic - Extrinsic Satisfaction Mediate the Prediction of General Job Satisfaction $\square$ ? The Journal of Psychology $\square$ : Interdisciplinary and Applied, 145(5), 435-461. https://doi.org/http://dx.doi.org/10.1080/00223980.2011.584082 PLEASE

[15] Cheah, C. S., Pee, V. S. W. C., Yeo, S. F., \& Wei, K. (2016). An Empirical Study on Factors Affecting Organizatuonal Commitment Among Generation X. Procedia - Social and Behavioral Sciences, $219,167-174$. https://doi.org/10.1016/j.sbspro.2016.05.002

[16] Chegini, Z., Janati, A., Asghari-Jafarabadi, M., \& Khosravizadeh, O. (2019). Organizational commitment, job satisfaction, organizational justice and self- efficacy among nurses. Journal of Nursing Practice Today, 6(2), 86-93. https://doi.org/https://doi.org/10.18502/npt.v6i2.913

[17] Chin, W. (1998). The Partial Least Squares Approach to Structural Equation Modeling (E. Modern Methods for Business Research, In: G. A. Marcoulides (ed.)). Lawrence Erlbaum Associates Publisher.

[18] Ćulibrk, J., Delić, M., Mitrović, S., \& Ćulibrk, D. (2018). Job satisfaction, organizational commitment and job involvement: The mediating role of job involvement. Frontiers in Psychology, 9(FEB), 1-12. https://doi.org/10.3389/fpsyg.2018.00132

[19] Darmawan, A., \& Putri, M. A. (2017). Pengaruh Gaya Kepemimpinan terhadap Komitmen Organisasi Melalui Kepuasan Kerja Sebagai Variabel Intervening. Akuntabilitas: Jurnal Ilmu Akuntansi, 10(1), 1-18. https://doi.org/10.15408/akt.v9i1.3581

[20] Fornell, C., \& Larcker, D. F. (1981). Evaluating Structural Equation Models with Unobservable Variables and Measurement Error. Journal of Marketing Research, 18(1), 39. https://doi.org/10.2307/3151312

[21] Ghozali, I. (2014). Structural Equation Modeling, Metode Alternatif dengan Partial Least Square (PLS) (4th ed.). Badan Penerbit Universitas Diponegoro.

[22] Greenberg, J. (1990). Organizational Justice: Yesterday, Today, and Tomorrow. Journal of Management, 16(2), 399-432. https://doi.org/10.1177/014920639001600208

[23] Greenberg, J. (2011). Behavior in Organizations Tenth Edition. Pearson Education.

[24] Hair, J. F., Black, W. C., Babin, B. J., \& Anderson, R. E. (2010). Multivariate Data Analysis (7th ed.). Pearson Prentice Hall.

[25] Hair, J. F., Hult, G. T., Ringle, C. M., \& Sarstedt, M. (2014). A primer partial least squaresstructural equation modeling (PLSSEM). SAGE Publications.

[26] Hazriyanto, \& Ibrahim, B. (2019). The factor analysis of organizational commitment, job satisfaction and performance among employees in Batam. Journal of Technical Education and Training, 11(1), 151-158. https://doi.org/10.30880/jtet.2019.11.01.19 
[27] Hutagalung, D., Asbari, M., Fayzhall, M., Ariyanto, E., Agistiawati, E., Sudiyono, R. N., Waruwu, H., Goestjahjanti, F. S., Winanti, \& Yuwono, T. (2020). Peran Religiusitas, Kepemimpinan Transformasional, Kepuasan Kerja dan Mediasi Organizational Citizenship Behavior terhadap Kinerja Guru. EduPsyCouns: Journal of Education, Psychology and Counseling, 2(1), 311-326. https://ummaspul.e-journal.id/Edupsycouns/article/view/483

[28] Imelda, D., Asbari, M., Purwanto, A., Sestri Goestjahjanti, F., \& Mustikasiwi, A. (2020). The Effect of Fairness of Performance Appraisal, Job Satisfaction and Commitment on Employees' Performance: Evidence from Indonesian Automotive Industry. International Journal of Advanced Science and Technology, 29(4), 2383-2396. https://doi.org/http://sersc.org/journals/index.php/IJAST/article/view/20519

[29] Ismail, A., \& Razak, M. R. A. (2016). Effect of Job Satisfaction on Organizational Commitment. Management\&Marketing, XIV(1), $25-40$.

[30] Jang, J., Lee, D. W., \& Kwon, G. (2019). An Analysis of the Influence of Organizational Justice on Organizational Commitment An Analysis of the Influence of Organizational Justice on Organizational. International Journal of Public Administration, 00(00), 1-9. https://doi.org/10.1080/01900692.2019.1672185

[31] Jiang, Z., Gollan, P. J., \& Brooks, G. (2015). Relationships between organizational justice, organizational trust and organizational commitment $\square:$ a crosscultural study of China , South Korea and Australia. 5192(January 2016). https://doi.org/10.1080/09585192.2015.1128457

[32] Kashif, M., Mahmood, B., \& Aijaz, S. (2016). Organizational Justice and Job Satisfaction in Banking Sector of Pakistan (A Study of Faisalabad). Global Journal of Management and Business Research: A Administration and Management, 16(6). https://www.journalofbusiness.org/index.php/GJMBR/article/view/1998/1900

[33] Kim, S. J., \& Chung, E. K. (2018). The effect of organizational justice as perceived by occupational drivers on traffic accidents: Mediating effects of job satisfaction. Journal of Safety Research, xxxx, 1-6. https://doi.org/10.1016/j.jsr.2018.11.001

[34] Kreitner, R., \& Kinicki, A. (2014). Perilaku Organisasi (9th ed.). Salemba Empat.

[35] Kusumaningsih, S. W., Ong, F., Hutagalung, D., Basuki, S., Asbari, M., \& Purwanto, A. (2020). Organizational Culture, Organizational Commitment and Employees' Performance $\square$ : The Mediating Role of Organizational Citizenship Behavior. TEST $\begin{array}{lllll}\text { Engineering and } & \text { 83(March-April }\end{array}$ http://www.testmagzine.biz/index.php/testmagzine/article/view/6958

[36] Lambert, E. G., Hogan, N. L., \& Griffin, M. L. (2007). The impact of distributive and procedural justice on correctional staff job stress, job satisfaction, and organizational commitment. Journal of Criminal Justice 35, 35, 644-656. https://doi.org/10.1016/j.jcrimjus.2007.09.001

[37] Lambert, E. G., Keena, L. D., Leone, M., May, D., \& Haynes, S. H. (2019). The effects of distributive and procedural justice on job satisfaction and organizational commitment of correctional staff. The Social Science Journal. https://doi.org/10.1016/j.soscij.2019.02.002

[38] Li, X., Zhang, J., Zhang, S., \& Zhou, M. (2016). Industrial Marketing Management A multilevel analysis of the role of interactional justice in promoting knowledge-sharing behavior $\square$ : The mediated role of organizational commitment. Industrial Marketing Management. https://doi.org/10.1016/j.indmarman.2016.09.006

[39] Luthans, F. (2005). Perilaku Organisasi (Edisi Kese). Penerbit ANDI.

[40] Meyer, J. P., \& Allen, N. J. (1991). A THREE-COMPONENT CONCEPTUALIZATION OF ORGANIZATIONAL COMMITMENT. Human Resource Management Review, 1(1), 61-89. https://doi.org/10.1016/1053-4822(91)90011-Z

[41] Meyer, J. P., Allen, N. J., \& Smith, C. A. (1993). Commitment to Organizations and Occupations $\square$ : Extension and Test of a Three Component Conceptualization. Journal of Applied Psychology, 78(4), 538-551. https://doi.org/https://doi.org/10.1037/00219010.78.4.538

[42] Minibas-Poussard, J., Le Roy, J., \& Erkmen, T. (2017). The moderating role of individual variables in the relationship between organizational justice and organizational commitment. Personnel Review, 46(8), 1635-1650. https://doi.org/https://doi.org/10.1108/PR-12-2015-0311

[43] Mohamad, M. S. (2012). Transformational Leadership and Employees' Job Satisfaction and Commitment: A Structural Equation Investigation. Journal of American Science, 8(7), 11-19. http://www.americanscience.org

[44] Moorman, R. H. (1991). Relationship Between Organizational Justice and Organizational Citizenship Behaviors: Do Fairness Perceptions Influence Employee Citizenship? Journal of Applied Psychology, 76(6), 845-855. https://doi.org/https://doi.org/10.1037/0021-9010.76.6.845

[45] Musringudin, Akbar, M., \& Karnati, N. (2017). The Effect of Organizational Justice, Job Satisfaction, and Organizational Commitment on Organizational Citizenship Behavior (OCB) of the Principles. Indonesian Journal of Educational Review, 4(2), $155-165$.

[46] Niehoff, B. P., \& Moorman, R. H. (1993). JUSTICE AS A MEDIATOR OE THE RELATIONSHIP BETWEEN METHODS OF MONITORING AND ORGANIZATIONAL CITIZENSHIP BEHAVIOR. Academy of Management Journal, 36(3), 527-557. https://doi.org/https://doi.org/10.5465/256591

[47] Pramono, R., Suyantoko, Purwanto, A., Kristiana, Y., Yuliantoro, N., \& Asbari, M. (2020). Implementation of Analysis of Talent Management in Family Business. International Journal of Advanced Science and Technology, 29(6), 6124-6146. http://sersc.org/journals/index.php/IJAST/article/view/19899 
[48] Putra, I. G. E. S. M., \& Indrawati, A. D. (2018). KERJA DAN KOMITMEN ORGANISASIONAL DI HOTEL RAMA PHALA UBUD. E-Jurnal Manajemen Unud, 7(4), 2010-2040. https://doi.org/https://doi.org/10.24843/EJMUNUD.2018.v7.i04.p11

[49] Rahman, A., Shahzad, N., Mustafa, K., Khan, M. F., \& Qurashi, F. (2016). Effects of Organizational Justice on Organizational Commitment. International Journal of Economics and Financial Issues, 6(S3), 188-196. https://search.proquest.com/openview/49bad9072f87d212dcd983be9a4d32d5/1?pq-origsite=gscholar\&cbl=816338

[50] Randolph, D. S. (2005). Predicting the Effect of Extrinsic and Intrinsic Job Satisfaction Factors on Recruitment and Retention of Rehabilitation Professionals. Journal of Healthcare Management, 50(1), 49-60.

[51] Robbins, S. P., \& Judge, T. A. (2001). Perilaku Organisasi (terj). Salemba Empat.

[52] Robbins, Stephen P., \& Judge, T. A. (2008). Organizational Behavior. Prentise Hall.

[53] Saadati, M., Saadati, A., Asghari, A., Bidgoli, M. G., \& Bidgoli, A. G. (2016). The Relationship between Perceived Organizational Justice, Organizational Commitment and Job Satisfaction. 3(1), 10-17. http://jhsme.muq.ac.ir/article-1-57-en.html

[54] Sekaran, U., \& Bougie, R. (2003). Research Methods For Business: A Skill Building Approach (Sixth edit). John Wiley and Sons, Inc.

[55] Soomro, B. A., \& Shah, N. (2019). Determining the impact of entrepreneurial orientation and organizational culture on job satisfaction, organizational commitment, and employee's performance. South Asian Journal of Business Studies, 8(3), 266-282. https://doi.org/10.1108/SAJBS-12-2018-0142

[56] Sudiyono, R. N., Fikri, M. A. A., Asbari, M., Suroso, Nugroho, Y. A., \& Singgih, E. (2020). The Role of Employee Engagement in the Relationship between Authentic Leadership , Talent Management and Job Satisfaction. International Journal of Advanced Science and Technology, 29(5), 11809-11836. http://sersc.org/journals/index.php/IJAST/article/view/25377

[57] Afridi, A. A., \& Baloch, Q. B. (2018). The Effect of Organizational Justice on Job Satisfaction: A Comparative Study of Public and Private Universities of Khyber Pakhtunkhwa. Abasyn Journal of Social Sciences, 11(1), 237-253.

[58] Agistiawati, E., Asbari, M., Basuki, S., Yuwono, T., \& Chidir, G. (2020). Exploring the Impact of Knowledge Sharing and Organizational Culture on Teacher Innovation Capability. International Journal of Science and Management Studies (IJSMS), 3(3), 62-77. http://www.ijsmsjournal.org/current-issue.html

[59] Ajala, E. M. (2017). A RELATIONSHIP STUDY BETWEEN ORGANISATIONAL JUSTICE AND JOB SATISFACTION AMONG INDUSTRIAL EMPLOYEES IN OGUN STATE, NIGERIA. AFRICAN JOURNAL FOR THE PSYCHOLOGICAL STUDY OF SOCIAL ISSUES, 20(2), 26-42. http://www.ajpssi.org/index.php/ajpssi/article/view/223

[60] Allen, N. J., \& Meyer, J. P. (1990). The measurement and antecedents of affective, continuance and normative commitment to the organization. Journal of Occupational Psychology, 63, 1-18. https://doi.org/https://doi.org/10.1111/j.2044-8325.1990.tb00506.x

[61] Asbari, M. (2015). Fokus Satu Hebat. Penerbit Dapur Buku.

[62] Asbari, M. (2019). Pengaruh kepemimpinan transformasional dan iklim organisasi terhadap kinerja dosen. JOCE IP, 13(2), 172186. http://jurnal.ipem.ac.id/index.php/joce-ip/article/view/187

[63] Asbari, M., Bernarto, I., Pramono, R., Purwanto, A., Hidayat, D., Sopa, A., Alamsyah, V. U., Senjaya, P., Fayzhall, M., \& Mustofa. (2020). The effect of work-family conflict on job satisfaction and performance: A study of Indonesian female employees International Journal of Advanced Science and Technology, 29(3), 6724-6748. http://sersc.org/journals/index.php/IJAST/article/view/7325

[64] Asbari, M., Fayzhall, M., Goestjahjanti, F. S., Winanti, Yuwono, T., Hutagalung, D., Basuki, S., Maesaroh, S., Mustofa, Chidir, G., Yani, A., \& Purwanto, A. (2020). Peran Kepemimpinan Transformasional Dan Organisasi Pembelajaran Terhadap Kapasitas Inovasi Sekolah. EduPsyCouns: Journal of Education, Psychology and Counseling, 2(1), 6724-6748. https://ummaspul.ejournal.id/Edupsycouns/article/view/421

[65] Asbari, M., Purwanto, A., \& Santoso, P. B. (2019). Influence of Leadership, Motivation, Competence, Commitment and Culture on ISO 9001:2015 Performance in Packaging Industry. Scholars Journal of Economics, Business and Management, 8875, 577-582. https://doi.org/10.36347/sjebm.2019.v06i12.005

[66] Bayarçelik, E. B., \& Findikli, M. A. (2016). The Mediating Effect of Job Satisfaction On The Relation Between Organizational Justice Perception And Intention To Leave. Procedia - Social and Behavioral Sciences, 235(October), 403-411. https://doi.org/10.1016/j.sbspro.2016.11.050

[67] Bayasgalan, T., \& Gerelkhuu, T. (2016). THE IMPACTS OF ORGANIZATIONAL JUSTICE AND CULTURE, KNOWLEDGE MANAGEMENT AND EMPLOYEE ENGAGEMENT ON EMPLOYEE'S JOB SATISFACTION: THE CASE OF SUPPORTIVE SERVICE OFFICERS. Mongolian Journal of Agricultural Sciences, 19(3), 56-65. https://mongoliajol.info/index.php/MJAS/article/view/736

[68] Bernarto, I., Bachtiar, D., Sudibjo, N., Suryawan, I. N., Purwanto, A., \& Asbari, M. (2020). Effect of transformational leadership, perceived organizational support, job satisfaction toward life satisfaction: Evidences from indonesian teachers. International Journal of Advanced Science and Technology, 29(3), 5495-5503. http://sersc.org/journals/index.php/IJAST/article/view/6057

[69] Beshlideh, K., Sharifi, R., Hashemi, S. E., \& Naami, A. (2018). Testing a model of perceived organizational support, citizenship behavior, commitment, job satisfaction and leader-member exchange as concequences of servant leadership in cement factory employees in Kermanshah. International Journal of Psychology (IPA), 12(2), 169-196. https://doi.org/10.24200/ijpb.2018.115440.

[70] Calvo-salguero, A., Salinas, J., Martínez-de-Lecea, \& Carrasco-González, A.-M. (2011). Work - Family and Family - Work 
Conflict $\square$ : Does Intrinsic - Extrinsic Satisfaction Mediate the Prediction of General Job Satisfaction $\square$ ? The Journal of Psychology $\square$ : Interdisciplinary and Applied, 145(5), 435-461. https://doi.org/http://dx.doi.org/10.1080/00223980.2011.584082 PLEASE

[71] Cheah, C. S., Pee, V. S. W. C., Yeo, S. F., \& Wei, K. (2016). An Empirical Study on Factors Affecting Organizatuonal Commitment Among Generation X. Procedia - Social and Behavioral Sciences, $219,167-174$. https://doi.org/10.1016/j.sbspro.2016.05.002

[72] Chegini, Z., Janati, A., Asghari-Jafarabadi, M., \& Khosravizadeh, O. (2019). Organizational commitment, job satisfaction, organizational justice and self- efficacy among nurses. Journal of Nursing Practice Today, 6(2), 86-93. https://doi.org/https://doi.org/10.18502/npt.v6i2.913

[73] Chin, W. (1998). The Partial Least Squares Approach to Structural Equation Modeling (E. Modern Methods for Business Research, In: G. A. Marcoulides (ed.)). Lawrence Erlbaum Associates Publisher.

[74] Ćulibrk, J., Delić, M., Mitrović, S., \& Ćulibrk, D. (2018). Job satisfaction, organizational commitment and job involvement: The mediating role of job involvement. Frontiers in Psychology, 9(FEB), 1-12. https://doi.org/10.3389/fpsyg.2018.00132

[75] Darmawan, A., \& Putri, M. A. (2017). Pengaruh Gaya Kepemimpinan terhadap Komitmen Organisasi Melalui Kepuasan Kerja Sebagai Variabel Intervening. Akuntabilitas: Jurnal Ilmu Akuntansi, 10(1), 1-18. https://doi.org/10.15408/akt.v9i1.3581

[76] Fornell, C., \& Larcker, D. F. (1981). Evaluating Structural Equation Models with Unobservable Variables and Measurement Error. Journal of Marketing Research, 18(1), 39. https://doi.org/10.2307/3151312

[77] Ghozali, I. (2014). Structural Equation Modeling, Metode Alternatif dengan Partial Least Square (PLS) (4th ed.). Badan Penerbit Universitas Diponegoro.

[78] Greenberg, J. (1990). Organizational Justice: Yesterday, Today, and Tomorrow. Journal of Management, 16(2), 399-432. https://doi.org/10.1177/014920639001600208

[79] Greenberg, J. (2011). Behavior in Organizations Tenth Edition. Pearson Education.

[80] Hair, J. F., Black, W. C., Babin, B. J., \& Anderson, R. E. (2010). Multivariate Data Analysis (7th ed.). Pearson Prentice Hall.

[81] Hair, J. F., Hult, G. T., Ringle, C. M., \& Sarstedt, M. (2014). A primer partial least squaresstructural equation modeling (PLSSEM). SAGE Publications.

[82] Hazriyanto, \& Ibrahim, B. (2019). The factor analysis of organizational commitment, job satisfaction and performance among employees in Batam. Journal of Technical Education and Training, 11(1), 151-158. https://doi.org/10.30880/jtet.2019.11.01.19

[83] Hutagalung, D., Asbari, M., Fayzhall, M., Ariyanto, E., Agistiawati, E., Sudiyono, R. N., Waruwu, H., Goestjahjanti, F. S., Winanti, \& Yuwono, T. (2020). Peran Religiusitas, Kepemimpinan Transformasional, Kepuasan Kerja dan Mediasi Organizational Citizenship Behavior terhadap Kinerja Guru. EduPsyCouns: Journal of Education, Psychology and Counseling, 2(1), 311-326. https://ummaspul.e-journal.id/Edupsycouns/article/view/483

[84] Imelda, D., Asbari, M., Purwanto, A., Sestri Goestjahjanti, F., \& Mustikasiwi, A. (2020). The Effect of Fairness of Performance Appraisal, Job Satisfaction and Commitment on Employees' Performance: Evidence from Indonesian Automotive Industry. International Journal of Advanced Science and Technology, 29(4), 2383-2396. https://doi.org/http://sersc.org/journals/index.php/IJAST/article/view/20519

[85] Ismail, A., \& Razak, M. R. A. (2016). Effect of Job Satisfaction on Organizational Commitment. Management\&Marketing, XIV(1), 25-40.

[86] Jang, J., Lee, D. W., \& Kwon, G. (2019). An Analysis of the Influence of Organizational Justice on Organizational Commitment An Analysis of the Influence of Organizational Justice on Organizational. International Journal of Public Administration, 00(00), 1-9. https://doi.org/10.1080/01900692.2019.1672185

[87] Jiang, Z., Gollan, P. J., \& Brooks, G. (2015). Relationships between organizational justice, organizational trust and organizational commitment $\square:$ a crosscultural study of China , South Korea and Australia. 5192(January 2016). https://doi.org/10.1080/09585192.2015.1128457

[88] Kashif, M., Mahmood, B., \& Aijaz, S. (2016). Organizational Justice and Job Satisfaction in Banking Sector of Pakistan (A Study of Faisalabad). Global Journal of Management and Business Research: A Administration and Management, 16(6). https://www.journalofbusiness.org/index.php/GJMBR/article/view/1998/1900

[89] Kim, S. J., \& Chung, E. K. (2018). The effect of organizational justice as perceived by occupational drivers on traffic accidents: Mediating effects of job satisfaction. Journal of Safety Research, xxxx, 1-6. https://doi.org/10.1016/j.jsr.2018.11.001

[90] Kreitner, R., \& Kinicki, A. (2014). Perilaku Organisasi (9th ed.). Salemba Empat.

[91] Kusumaningsih, S. W., Ong, F., Hutagalung, D., Basuki, S., Asbari, M., \& Purwanto, A. (2020). Organizational Culture, Organizational Commitment and Employees 'Performance $\square$ : The Mediating Role of Organizational Citizenship Behavior. TEST Engineering and Management, 83(March-April 2020), http://www.testmagzine.biz/index.php/testmagzine/article/view/6958

[92] Lambert, E. G., Hogan, N. L., \& Griffin, M. L. (2007). The impact of distributive and procedural justice on correctional staff job stress , job satisfaction, and organizational commitment. Journal of Criminal Justice 35, 35, 644-656. https://doi.org/10.1016/j.jcrimjus.2007.09.001 
[93] Lambert, E. G., Keena, L. D., Leone, M., May, D., \& Haynes, S. H. (2019). The effects of distributive and procedural justice on job satisfaction and organizational commitment of correctional staff. The Social Science Journal. https://doi.org/10.1016/j.soscij.2019.02.002

[94] Li, X., Zhang, J., Zhang, S., \& Zhou, M. (2016). Industrial Marketing Management A multilevel analysis of the role of interactional justice in promoting knowledge-sharing behavior $\square$ : The mediated role of organizational commitment. Industrial Marketing Management. https://doi.org/10.1016/j.indmarman.2016.09.006

[95] Luthans, F. (2005). Perilaku Organisasi (Edisi Kese). Penerbit ANDI.

[96] Meyer, J. P., \& Allen, N. J. (1991). A THREE-COMPONENT CONCEPTUALIZATION OF ORGANIZATIONAL COMMITMENT. Human Resource Management Review, 1(1), 61-89. https://doi.org/10.1016/1053-4822(91)90011-Z

[97] Meyer, J. P., Allen, N. J., \& Smith, C. A. (1993). Commitment to Organizations and Occupations $\square$ : Extension and Test of a ThreeComponent Conceptualization. Journal of Applied Psychology, 78(4), 538-551. https://doi.org/https://doi.org/10.1037/00219010.78.4.538

[98] Minibas-Poussard, J., Le Roy, J., \& Erkmen, T. (2017). The moderating role of individual variables in the relationship between organizational justice and organizational commitment. Personnel Review, 46(8), 1635-1650. https://doi.org/https://doi.org/10.1108/PR-12-2015-0311

[99] Mohamad, M. S. (2012). Transformational Leadership and Employees' Job Satisfaction and Commitment: A Structural Equation Investigation. Journal of American Science, 8(7), 11-19. http://www.americanscience.org

[100] Moorman, R. H. (1991). Relationship Between Organizational Justice and Organizational Citizenship Behaviors: Do Fairness Perceptions Influence Employee Citizenship? Journal of Applied Psychology, 76(6), 845-855. https://doi.org/https://doi.org/10.1037/0021-9010.76.6.845

[101] Musringudin, Akbar, M., \& Karnati, N. (2017). The Effect of Organizational Justice, Job Satisfaction, and Organizational Commitment on Organizational Citizenship Behavior (OCB) of the Principles. Indonesian Journal of Educational Review, 4(2), $155-165$.

[102] Niehoff, B. P., \& Moorman, R. H. (1993). JUSTICE AS A MEDIATOR OE THE RELATIONSHIP BETWEEN METHODS OF MONITORING AND ORGANIZATIONAL CITIZENSHIP BEHAVIOR. Academy of Management Journal, $36(3), 527-557$. https://doi.org/https://doi.org/10.5465/256591

[103] Pramono, R., Suyantoko, Purwanto, A., Kristiana, Y., Yuliantoro, N., \& Asbari, M. (2020). Implementation of Analysis of Talent Management in Family Business. International Journal of Advanced Science and Technology, 29(6), 6124-6146. http://sersc.org/journals/index.php/IJAST/article/view/19899

[104] Putra, I. G. E. S. M., \& Indrawati, A. D. (2018). KERJA DAN KOMITMEN ORGANISASIONAL DI HOTEL RAMA PHALA UBUD. E-Jurnal Manajemen Unud, 7(4), 2010-2040. https://doi.org/https://doi.org/10.24843/EJMUNUD.2018.v7.i04.p11

[105] Rahman, A., Shahzad, N., Mustafa, K., Khan, M. F., \& Qurashi, F. (2016). Effects of Organizational Justice on Organizational Commitment. International Journal of Economics and Financial Issues, 6(S3), 188-196. https://search.proquest.com/openview/49bad9072f87d212dcd983be9a4d32d5/1?pq-origsite=gscholar\&cbl=816338

[106] Randolph, D. S. (2005). Predicting the Effect of Extrinsic and Intrinsic Job Satisfaction Factors on Recruitment and Retention of Rehabilitation Professionals. Journal of Healthcare Management, 50(1), 49-60.

[107] Robbins, S. P., \& Judge, T. A. (2001). Perilaku Organisasi (terj). Salemba Empat.

[108] Robbins, Stephen P., \& Judge, T. A. (2008). Organizational Behavior. Prentise Hall.

[109] Saadati, M., Saadati, A., Asghari, A., Bidgoli, M. G., \& Bidgoli, A. G. (2016). The Relationship between Perceived Organizational Justice, Organizational Commitment and Job Satisfaction. 3(1), 10-17. http://jhsme.muq.ac.ir/article-1-57-en.html

[110] Sekaran, U., \& Bougie, R. (2003). Research Methods For Business: A Skill Building Approach (Sixth edit). John Wiley and Sons, Inc.

[111] Soomro, B. A., \& Shah, N. (2019). Determining the impact of entrepreneurial orientation and organizational culture on job satisfaction, organizational commitment, and employee's performance. South Asian Journal of Business Studies, 8(3), 266-282. https://doi.org/10.1108/SAJBS-12-2018-0142

[112] Sudiyono, R. N., Fikri, M. A. A., Asbari, M., Suroso, Nugroho, Y. A., \& Singgih, E. (2020). The Role of Employee Engagement in the Relationship between Authentic Leadership , Talent Management and Job Satisfaction. International Journal of Advanced Science and Technology, 29(5), 11809-11836. http://sersc.org/journals/index.php/IJAST/article/view/25377

[113] Sudiyono, R. N., Goestjahjanti, F. S., Asbari, M., Fayzhall, M., Yani, A., Winanti, Yuwono, T., Nurasiah, Yulia, Y., Singgih, E., \& Chidir, G. (2020). Meningkatkan Komitmen dan Kinerja Dosen $\square$ : Apa Peran Manajemen Perguruan Tinggi $\square$ ?EduPsyCouns: Journal of Education, Psychology and Counseling, 2(1), 337-352. https://ummaspul.e-journal.id/Edupsycouns/article/view/489/283

[114] Suifan, T. S., Diab, H., \& Abdallah, A. B. (2017). Does organizational justice affect turnover-intention in a developing country? The mediating role of job satisfaction and organizational commitment. Journal of Management Development, 36(9), 1137-1148. https://doi.org/https:// doi.org/10.1108/JMD-02-2017-0048

[115] Weiss, D. J., Dawis, R. V., \& England, G. W. (1967). Manual for the Minnesota Satisfaction Questionnaire. Minnesota Studies in Vocational Rehabilitation, 22, 120. https://psycnet.apa.org/record/1968-08111-001 
[116] Yuwono, T., Novitasari, D., Asbari, M., Sutardi, D., Mustofa, \& Asbari, M. (2020). Peran Organizational Commitment terhadap Hubungan Work- Family Conflict dan Kepuasan Kerja Karyawan Wanita di Kota Seribu Industri Indonesia. EduPsyCouns: Journal of Education, Psychology and Counseling, 2(1), 524-540. https://ummaspul.e-journal.id/Edupsycouns/article/view/526/303

\section{APPENDIX:}

\section{VARIABLE AND ITEMS LIST}

\begin{tabular}{|c|c|c|c|c|}
\hline Variables & Dimensions & Items & Items Description & References \\
\hline \multirow[t]{18}{*}{$\begin{array}{l}\text { Organizational } \\
\text { justice }\end{array}$} & $\begin{array}{l}\text { Distributive } \\
\text { Justice }\end{array}$ & OJ1 & $\begin{array}{l}\text { Receiving a reward as a form of responsibility } \\
\text { in organization for what I have worked. }\end{array}$ & (Moorman, 1991) \\
\hline & & $\mathrm{OJ} 2$ & $\begin{array}{l}\text { Receiving a reward in a fair way based on the } \\
\text { working experience I have done. }\end{array}$ & \\
\hline & & OJ3 & $\begin{array}{l}\text { Receiving a reward fairly for the amount of } \\
\text { effort I have given to the organization. }\end{array}$ & \\
\hline & & OJ4 & $\begin{array}{l}\text { Receiving a reward fairly for the job I have } \\
\text { done well }\end{array}$ & \\
\hline & & OJ5 & $\begin{array}{l}\text { Receiving a reward correspond to the needs } \\
\text { fairly for the work pressure I have been through. }\end{array}$ & \\
\hline & $\begin{array}{l}\text { Procedural } \\
\text { Justice }\end{array}$ & OJ6 & $\begin{array}{l}\text { Procedure is designed to collect information } \\
\text { accurately that is needed to make a decision. }\end{array}$ & \\
\hline & & OJ7 & $\begin{array}{l}\text { Procedure is designed to give probability for } \\
\text { appeal or against a particular decision. }\end{array}$ & \\
\hline & & OJ8 & $\begin{array}{l}\text { Procedure is designed so all perspectives is } \\
\text { influenced by the decision that is represented. }\end{array}$ & \\
\hline & & OJ9 & $\begin{array}{l}\text { Procedure is designed to produce standards so } \\
\text { that decisions would be made consistently. }\end{array}$ & \\
\hline & & OJ10 & $\begin{array}{l}\text { Procedure is designed to listen to any concerns } \\
\text { from all perspectives that are impacted from the } \\
\text { decision. }\end{array}$ & \\
\hline & & OJ11 & $\begin{array}{l}\text { Procedure is designed to give beneficial } \\
\text { feedback regarding decision and its } \\
\text { implementation. }\end{array}$ & \\
\hline & & OJ12 & $\begin{array}{l}\text { Procedure is designed to give possibility to any } \\
\text { request so clarification could be done or the } \\
\text { presence of additional information regarding } \\
\text { decisions that have made. }\end{array}$ & \\
\hline & $\begin{array}{l}\text { Interactional } \\
\text { Justice }\end{array}$ & OJ13 & $\begin{array}{l}\text { Employer respects the point of view that you } \\
\text { have. }\end{array}$ & \\
\hline & & OJ14 & Employer is able to push personal bias & \\
\hline & & OJ15 & $\begin{array}{l}\text { Employers spare their time to give feedback } \\
\text { regarding something that should be discussed } \\
\text { and its implications. }\end{array}$ & \\
\hline & & OJ16 & $\begin{array}{l}\text { Employers treat you well and full of } \\
\text { consideration. }\end{array}$ & \\
\hline & & OJ17 & $\begin{array}{l}\text { Employers show their concern towards your } \\
\text { rights as an employee. }\end{array}$ & \\
\hline & & OJ18 & $\begin{array}{l}\text { Employer takes a step to make decision in an } \\
\text { appropriate way. }\end{array}$ & \\
\hline \multirow[t]{13}{*}{ Job Satisfaction } & $\begin{array}{l}\text { Intrinsic } \\
\text { Satisfaction }\end{array}$ & JS1 & $\begin{array}{l}\text { I have the opportunity to work correspond to my } \\
\text { capability. }\end{array}$ & (Weiss et al., 1967) \\
\hline & & JS2 & I feel an accomplishment when I work well. & \\
\hline & & JS3 & Working is a daily activity to keep people busy. & \\
\hline & & JS4 & $\begin{array}{l}\text { I have the opportunity to manage the things } \\
\text { people should work on. }\end{array}$ & \\
\hline & & JS5 & $\begin{array}{l}\text { I have the opportunity to try any method in } \\
\text { doing work. }\end{array}$ & \\
\hline & & JS6 & I have the opportunity to work independently. & \\
\hline & & JS7 & I do my work correspond to my conscience. & \\
\hline & & JS8 & I am responsible towards self-assessment. & \\
\hline & & JS9 & I feel comfortable working with certainty. & \\
\hline & & JS10 & $\begin{array}{l}\text { I have the opportunity in doing something for } \\
\text { other people. }\end{array}$ & \\
\hline & & JS11 & $\begin{array}{l}\text { I have the opportunity to be someone else in the } \\
\text { work environment. }\end{array}$ & \\
\hline & & JS12 & $\begin{array}{l}\text { I have the opportunity to do different activities } \\
\text { from time to time. }\end{array}$ & \\
\hline & Extrinsic & JS13 & I have the opportunity to obtain things that & \\
\hline
\end{tabular}




\begin{tabular}{|c|c|c|c|}
\hline & Satisfaction & & supports my \\
\hline & & JS14 & $\begin{array}{l}\text { I have the ability to demonstrate policy that is } \\
\text { applied in my workplace. }\end{array}$ \\
\hline & & JS15 & $\begin{array}{l}\text { I received salary that is proportional to work I } \\
\text { have done. }\end{array}$ \\
\hline & & JS16 & $\begin{array}{l}\text { I received compliments when doing my work } \\
\text { well. }\end{array}$ \\
\hline & & JS17 & $\begin{array}{l}\text { Employer gives a good attention to the } \\
\text { employee. }\end{array}$ \\
\hline & & JS18 & $\begin{array}{l}\text { Employer has the ability to make a right } \\
\text { decision. }\end{array}$ \\
\hline Organizational & Affective & OC1 & I am glad to spend my career in this \\
\hline Commitment & Commitment & & organization. \\
\hline & & $\mathrm{OC} 2$ & $\begin{array}{l}\text { I am glad to tell other people about my } \\
\text { workplace. }\end{array}$ \\
\hline & & OC3 & $\begin{array}{l}\text { The problem in this organization is also a part of } \\
\text { my problem. }\end{array}$ \\
\hline & & $\mathrm{OC} 4$ & $\begin{array}{l}\text { I am thinking to be easily involved with other } \\
\text { organization as easy as having a career these } \\
\text { days. }\end{array}$ \\
\hline & & OC5 & I felt like I am not a part of this big family. \\
\hline & & OC6 & $\begin{array}{l}\text { I felt like I am not emotionally involved in this } \\
\text { organization. }\end{array}$ \\
\hline & & $\mathrm{OC} 7$ & $\begin{array}{l}\text { This organization has a lot of personal meaning } \\
\text { for me. }\end{array}$ \\
\hline & & OC8 & $\begin{array}{l}\text { I don't feel any sense of belonging in this } \\
\text { organization. }\end{array}$ \\
\hline & $\begin{array}{l}\text { Continuance } \\
\text { Commitment }\end{array}$ & OC9 & $\begin{array}{l}\text { I am not afraid of what would happen if I } \\
\text { resigned from my work without thinking of } \\
\text { other things. }\end{array}$ \\
\hline & & OC10 & $\begin{array}{l}\text { Despite of wanting, it is hard to leave from this } \\
\text { organization. }\end{array}$ \\
\hline & & OC11 & $\begin{array}{l}\text { Too many things that would be distracted if I } \\
\text { decided to leave this organization. }\end{array}$ \\
\hline & & OC12 & I don't feel any loss if I leave this organization. \\
\hline & & $\mathrm{OC} 13$ & Working in this organization is my life necessity. \\
\hline & & OC14 & $\begin{array}{l}\text { Right now, I only have a few choices to } \\
\text { consider to leave this organization. }\end{array}$ \\
\hline & & OC15 & $\begin{array}{l}\text { One of the few serious consequences from } \\
\text { leaving this organization is alternative scarcity } \\
\text { that is available. }\end{array}$ \\
\hline & & OC16 & $\begin{array}{l}\text { One of the reasons I survive in this organization } \\
\text { is because of the difficulty to find a suitable job } \\
\text { in other organization. }\end{array}$ \\
\hline & $\begin{array}{l}\text { Normative } \\
\text { Commitment }\end{array}$ & OC17 & $\begin{array}{l}\text { I felt like other people is easy to change } \\
\text { from one organization to the other. }\end{array}$ \\
\hline & & OC18 & $\begin{array}{l}\text { I am not sure when a person should also be loyal } \\
\text { to the organization. }\end{array}$ \\
\hline & & OC19 & $\begin{array}{l}\text { It is not ethical for me when a person } \\
\text { chases their career by jumping from one } \\
\text { organization to another. }\end{array}$ \\
\hline & & OC20 & $\begin{array}{l}\text { One of the main reasons I keep on working } \\
\text { for this organization is trust and loyalty as } \\
\text { a moral obligation to survive. }\end{array}$ \\
\hline & & $\mathrm{OC} 21$ & $\begin{array}{l}\text { Despite of being offered for a better job, } \\
\text { leaving this organization is not the right } \\
\text { thing to do now. }\end{array}$ \\
\hline & & OC22 & $\begin{array}{l}\text { I feel like there should be a strong particular } \\
\text { value to be more loyal in this organization. }\end{array}$ \\
\hline
\end{tabular}

